\title{
Recovery Plan for the Non-Elutable lon Exchange Salt Alternative
}

by

D. D. Walker

Westinghouse Savannah River Company

Savannah River Site

Aiken, South Carolina 29808

This paper was prepared in connection with work done under the above contract number with the U. S. Department of Energy. By acceptance of this paper, the publisher and/or recipient acknowledges the U.S. Government's right to retain a nonexclusive, royalty-free license in and to any copyright covering this paper, along with the right to reproduce and to authorize others to reproduce all or part of the copyrighted paper. 


\section{DISCLAIMER}

This report was prepared as an account of work sponsored by an agency of the United States Government. Neither the United States Government nor any agency thereof, nor any of their employees, makes any warranty, express or implied, or assumes any legal liability or responsibility for the accuracy, completeness, or usefulness of any information, apparatus, product, or process disclosed, or represents that its use would not infringe privately owned rights. Reference herein to any specific commercial product, process, or service by trade name, trademark, manufacturer, or otherwise does not necessarily constitute or imply its endorsement, recommendation, or favoring by the United States Government or any agency thereof. The views and opinions of authors expressed herein do not necessarily state or reflect those of the United States Government or any agency thereof.

This report has been reproduced directly from the best available copy.

Available to DOE and DOE contractors from the Office of Scientific and Technical Information, P. O. Box 62, Oak Ridge, TN 37831; prices available from (423) 576-8401.

Available to the public from the National Technical Information Service, U. S. Department of Commerce, 5285 Port Royal Road, Springfield, VA 22161. 


\section{DISCLAIMER}

Portions of this document may be illegible in electronic image products. Images are produced from the best available original document. 
WSRC-RP-99-00568, Rev.0

Keywords: Salt alternatives, crystalline silicotitanate, salt processing

Retention: Permanent

\section{RECOVERY PLAN FOR THE NON-ELUTABLE ION EXCHANGE SALT ALTERNATIVE}

D. D. Walker

Publication Date: July 6, 1999

Westinghouse Savannah River Company Savannah River Technology Center

Aiken, SC 29808

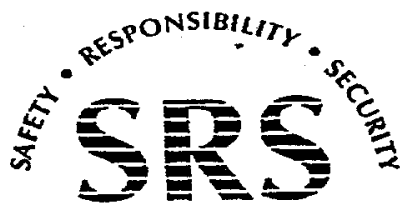


WSRC-RP-99-00568, Rev.0

Page 2 of 9

Recovery Plan for the Non-Elutable Ion Exchange Salt Alternative

Author

DarrelOlialker

$717 / 99$

D. D. Walker, Waste Processing Technology

Date

Approvals

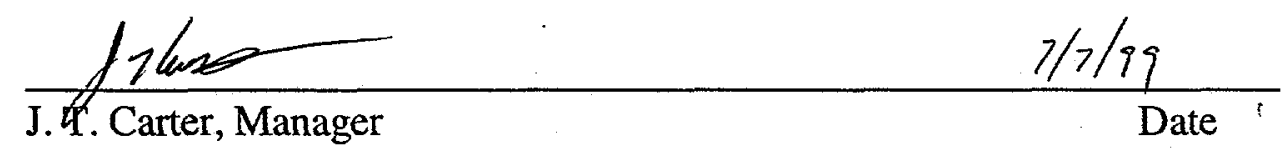

High Level Waste - Process Engineering

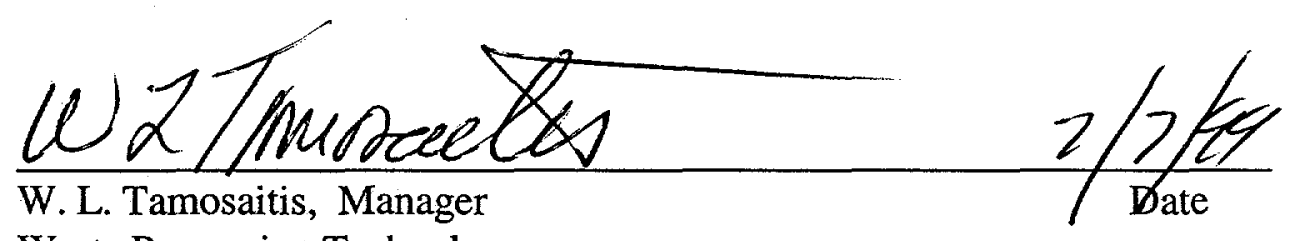

Waste Processing Technology

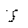




\section{RECOVERY PLAN FOR THE NON-ELUTABLE ION EXCHANGE SALT ALTERNATIVE}

\section{SUMMARY}

Observations during experiments with UOP IONSIV ${ }^{\mathrm{TM}}$ IE-911 during the past year and information obtained during technical discussions with UOP, LLC, personnel in June 8, 1999 , generated technical questions concerning the application of crystalline silicotitanate (CST) to Savannah River Site (SRS) soluble waste decontamination. The following tasks are recommended to provide the additional information needed for an adequate evaluation of non-elutable ion exchange during Phase IV of the Salt Alternatives selection process.

- Stability tests in SRS simulated waste solutions to include short-term batch tests and additional analyses in the Savannah River Technology Center (SRTC) radioactive waste test and in the Oak Ridge National Laboratory (ORNL) leach tests.

- Additional measurements of the effect of temperature on capacity ( $\mathrm{K}_{\mathrm{d}}$ tests) to include error analysis of previous results, comparison of different production lots, and comparison to IONSIVTM IE-910 over the temperature range $25-35^{\circ} \mathrm{C}$.

- Determine the effect of pretreatment and simulated waste on chloride in IONSIVTM IE-911 and estimate the chloride concentrations in process streams.

- Measure the impact of gas bubbles on column capacity.

Resources within SRTC, ORNL, Argonne National Laboratory, and UOP, LLC, will be engaged as appropriate to accomplish these tasks prior to the September 1999 Phase IV decision.

The last item on the list above (i.e., a test to measure impact of gas bubbles on column capacity) is part of the current scope of work, but a new approach to this test is described below. Additional areas of investigation were identified but are not considered critical to support the September 1999 Phase IV decision. These items are discussed at the end of this report and should be considered for investigation following the Phase IV decision.

\section{INTRODUCTION}

Following the Phase III evaluation of salt processing alternatives, additional research on non-elutable ion exchange, small tank tetraphenylborate, and direct grout options was initiated. The current work includes several areas of research for the non-elutable ion exchange process: effect of gas generation and organic compounds on column 
glass formulation. Preliminary results from these experiments, recent observations by SRTC researchers, and information obtained from UOP, LLC, suggest additional testing of IONSIVTM IE-911 that may greatly assist the Phase IV decision scheduled for September 1999. A discussion of proposed investigations follows.

\section{TESTS PROPOSED FOR PHASE IV}

Results from the tests described in the following sections are desirable prior to the Phase IV decision of the Salt Alternatives selection process.

\section{Stability of IONSIVTM IE-911 in Simulated Salt Solutions}

The following observations suggest IONSIV ${ }^{\mathrm{TM}}$ IE-911 reacts with simulated waste solutions:

a. Contact between $\operatorname{Lot}^{1}$ 98-5 material and simulated waste salt solutions turned the solutions yellow.

b. Irradiation of Lot $98-5$ material in the presence of salt solution resulted in the solution becoming yellow and hazy.

c. When salt solutions entered ion exchange columns, the upper portions of the column bed turned brown and in one case the column plugged.

d. Portions of Lot 96-4 exposed to salt solution showed Si enrichment or, conversely, Ti depletion relative to untreated particles when examined by Energy Dispersive X-ray Spectroscopy (EDXS). In addition, some scanning electron microscopy (SEM) photographs suggest $\mathrm{NaOH}$ treatment enlarged the macropores.

Several processing problems could result from reactions between IONSIV ${ }^{\mathrm{TM}}$ IE-911 and the waste solution. If a component of the waste precipitates on the IONSIV ${ }^{\mathrm{TM}} \mathbb{E}-911$, the adsorbent particles could cement together preventing removal from the process equipment or the macropores could congest thereby slowing cesium sorption. If the precipitating particles freely migrate, the column packing may filter the resulting solids and hinder liquid flow. If the waste leaches a component from the particles, the adsorbent particles could loose integrity and plug the column or radioactive particles exit the column in the process stream. If additional testing confirms a reaction between salt solutions and IONSIVTM IE-911, research should attempt to distinguish between these potential mechanisms. Test conditions for this work should reflect normal process . operations. Given these observation and potential technology risks, the following additional tasks will be performed.

- Short-term batch tests to confirm and elucidate the previous observations. In these test, portions of IONSIVTM IE-911 are contacted with simulated SRS waste solutions for a period of time. Following contact, the salt solution will be analyzed for changes in composition, fines collected and analyzed for

\footnotetext{
${ }^{1}$ For simplicity, this report abbreviates the UOP lot numbers as shown in the following example: $9990-98$ $81-0005$ as $98-5$.
} 
composition, and the treated IONSIV ${ }^{\mathrm{TM}}$ IE-911 examined for surface changes. Variables and the recommended ranges include salt solution composition (average, high hydroxide, and high nitrate formulations), temperature $\left(25-35^{\circ} \mathrm{C}\right)$, radiation $(0$ and $50 \mathrm{Mrad})$, and time ( 0 to 7 days). Execution of this work is being pursued with John D. Sherman and Dennis J. Fennelly of UOP.

- Post-mortem analysis of IONSIVTM IE-911 used in ORNL leach tests. These tests are underway at ORNL under the direction of Paul Taylor. At the end of the tests, the salt solution should be analyzed for changes in composition, fines collected and analyzed for composition, and the treated IONSIVTM IE-911 examined for surface changes.

- The radioactive waste column test in the SRS Shielded Cells Facility should be expanded to include analysis for radioactive fines in the column effluent. The presence of radioactive fines can be detected by measuring the effluent from the first short column before and after filtering through an appropriate filter with submicron nominal pore size.

Accident conditions are not included in the proposed test matrix since the Phase IV evaluation does not include detailed accident analyses for any of the process options under consideration.

\section{Effect of Temperature on IONSIV ${ }^{\mathrm{TM}}$ IE-911 Capacity}

The following observations suggest that IONSIV ${ }^{\mathrm{TM}}$ IE-911 has less cesium capacity at slightly elevated temperatures than predicted by the Texas A\&M University (TAMU) model for IONSIVTM IE-910.

a. ORNL tests on Batch $98-5$ at 30 to $60^{\circ} \mathrm{C}$ yielded $\mathrm{K}_{d}$ values that were 25 to $35 \%$ lower than TAMU model predictions.

b. An SRTC test at $45^{\circ} \mathrm{C}$ yielded a $\mathrm{K}_{\mathrm{d}}$ of only $55 \%$ of TAMU model prediction.

The apparent discrepancy between the model and test results may be caused by low accuracy and precision of $K_{d}$ tests, or by binder effects. If the $K_{d}$ changes with temperature in the ORNL tests are expressed as percentages, then the results match the TAMU model predictions, suggesting the $\mathrm{K}_{\mathrm{d}}$ tests method is the cause of the discrepancy. The following additional work will resolve this discrepancy.

- The ORNL $K_{d}$ results should be repeated and simultaneously run against IONSIV TM IE-910 and other lots of IONSIV TM IE-911 at 25,35 , and $45^{\circ} \mathrm{C}$.

The results will provide an estimate of the reproducibility of the $\mathrm{K}_{\mathrm{d}}$ measurement, and indicate whether the low values at higher temperature are due to production lot variations or to the binder. Although the proposed temperature range exceeds expected process operations, the additional range will allow greater discrimination between $\mathrm{K}_{\mathrm{d}}$ reproducibility and binder effects. 


\section{Chloride in IONSIVTM IE-911}

As described by UOP, the production lots of IONSIV ${ }^{\mathrm{TM}}$ IE-911 tested at SRS and ORNL contained as much as a few weight percent chloride. This element is not listed on the Material Safety Data Sheets provided by the vendor. If present in uncontrolled amounts, chloride could cause corrosion problems within the Defense Waste Processing Facility (DWPF) or non-elutable ion exchange facilities. In addition to corrosion concerns, there is a chloride limit for the DWPF glass $(0.6 \mathrm{wt} \%)$. Although this limit is not challenged by the chloride in the IONSIV ${ }^{\mathrm{TM}} \mathrm{IE}-911$, it does add significantly to the sum of the chloride from all sources. Chloride ion in IONSIV ${ }^{\mathrm{TM}}$ IE-911 can potentially be removed by rinsing the resin with water or hydroxide solution and the chloride content lowered to an acceptable level. Alternatively, chloride could be removed by changes in the production process for IONSIVTM IE-911. The latter alternative may be the best longterm solution to any problems caused by chloride. However, in the short term, the available performance data for IONSIV ${ }^{\mathrm{TM}}$ IE-911 was obtained with the chloride material. Thus, in the short term, it is more feasible to demonstrate that chloride can be removed easily (without changing the production process significantly) than demonstrate a change in production process does not adversely affect performance. The following additional testing is suggested to support the decision in September.

- Determine whether or not pretreatment (washing with water or $\mathrm{NaOH}$ ) or column operations (washing with salt solution) removes chloride from IONSIVTM IE-911.

- Based on the chloride tests, revise the process material balance and identify potential chloride impacts on downstream processes.

\section{Gas Generation}

Calculated gas generation rates in a fully-loaded ion exchange column imply bubbles will form. The calculated result requires experimental verification, including measurement of the impact on column performance. If the impact on performance is significant, process or design changes may be required. Completion of the proposed experiment to run an ion exchange column in an SRTC Co-60 source $(1 \mathrm{Mrad} / \mathrm{h})$ appears unfeasible prior to the September decision due to the very slow flowrates required. However, the following experiment is still recommended.

- Measure cesium breakthrough in a column test in which gas is generated homogeneously at rates in excess of the amount soluble so that bubbles form.

The following alternative approach is suggested. Perform the experiment at higher dose rate $(10 \mathrm{Mrad} / \mathrm{h})$ and slower flow rate to achieve bubble formation. An appropriate radiation source at another DOE site is required. It is very desirable that the gas be generated radiolytically to simulate the mechanism that will occur in the process. If an acceptable radiation source is not available to run this test prior to the Phase IV decision, than another alternative approach must be found. An upflow test at $1 \mathrm{Mrad} / \mathrm{h}$ and slow 
flow rate to obtain gas saturation and bubble formation has been suggested. However, the decrease in flow rate extends the test duration sufficiently to preclude completion of the test prior to the Phase IV decision.

\section{ADDITIONAL TESTS CONSIDERED BUT NOT RECOMMENDED FOR IMMEDIATE ACTION}

The following additional tests were considered but are not recommended for action prior to the Phase IV decision of the Salt Alternatives selection process.

\section{Column Performance at Higher Temperatures}

Column tests of IONSIV TM IE-911 occurred at ambient temperatures although the process will likely operate between 25 and $35^{\circ} \mathrm{C}$. The temperature dependence of the distribution coefficients $\left(\mathrm{K}_{d}\right)$ for IONSIV ${ }^{\mathrm{TM}} \mathbb{E}$-911 suggest that columns will not perform as well at the higher temperature range. An estimate of the change in column capacity at higher temperatures can be obtained through the VERSE computer model. Eventually, however, column tests over the entire process operating range are needed.

- Measure cesium breakthrough in an ion exchange column test at $35^{\circ} \mathrm{C}$.

\section{Product Performance Variability}

The following observation suggests that product performance varies significantly between production batches.

- Column tests with Lot 96-4 show low capacity compared to other lots tested at identical conditions.

Other observations suggest measurable differences occur between production lots (e.g., 1998 lots feel "slicker" than earlier lots, and the temperature and intensity of a low temperature endotherm varies between lots). However, these observations have not been correlated with product performance. The similarity between production lots has previously been inferred by comparing $\mathrm{K}_{\mathrm{d}}$ measurements at specific conditions $\left(25^{\circ} \mathrm{C}\right.$, average waste composition). The $\mathrm{K}_{\mathbf{d}}$ measurement did not indicate a difference in column performance for Lot 96-4. The accuracy and precision of this method is suspect. A new method that measures capacity and kinetic performance is needed.

- Develop a simple and short test that predicts column performance (both kinetics and capacity).

- Compare performance of different production lots as the production process develops.

These items are unlikely to be resolved prior to the Phase IV decision due partly to the difficulty and partly to impending changes in the production process. However, previous column tests provide a limited estimate of product variability. 


\section{Binder Stability}

Oak Ridge National Laboratory heat capacity measurements and SRTC thermal gravimetric tests indicate a variable low temperature $\left(100-150^{\circ} \mathrm{C}\right)$ endothermic reaction and phase change associated with the binder. Treatment of the IONSIV ${ }^{\mathrm{TM}}$ IE-911 with sodium hydroxide solution eliminates the endothermic reaction. However, post-production changes in the binder may result in changes in particle integrity. In principle, differences in production batches are controllable with appropriate purchase specifications and acceptance tests.

- Correlate the magnitude of the endothermic reaction with particle integrity and performance by testing different production batches of IONSIV ${ }^{\mathrm{TM}}$ IE-911. Determine if thermal gravimetric analysis is a potential product acceptance test.

\section{Gas Generation Modeling}

Previous calculations of gas generation in an ion exchange column neglected potentially important phenomena such as pressure and temperature effects on the gas solubility. Improved calculations could better definition of the location and amount of bubbles forming in a large IX column.

- Develop a model of gas bubble formation that includes time and location dependent gas generation rates, and temperature and pressure dependence of the gas solubility. Use this model to define gas concentrations and generation rates in a large column. From the model results, plan and execute small scale tests to mimic specific zones within the column.

\section{Long-Term Stability of IONSIV ${ }^{\mathrm{TM}}$ IE-911 in Simulated Salt Solutions}

The short-term tests to investigate the stability of IONSIV IE-99 in simulated salt solutions did not include time increments approaching expected process operating cycles (i.e., up to 10 months). The observations that initiated the stability question were obtained in short-term tests, and thus, short-term tests are likely adequate to answer most questions. However, the observations also raise questions about the long-term stability which the following test is designed to answer.

- A long-term, continuous flow contact test should be initiated to examine the effects of exposure to salt solution through a full process cycle (up to 10 months). Differences between the feed and effluent compositions are not likely detectable. Periodically, portions of the treated IONSIV ${ }^{\text {TM }}$ IE-911 should be removed and analyzed.

Only interim results (possibly 2 months of exposure) will be available from the long-term test since it completes after the Phase IV decision. 
CC: G. E. Abell, 704-3N

J. L. Barnes, 704-3N

M. J. Barnes, 773-A

R. W. Blackmon, 704-3N

J. T. Carter, 704-3N

C. L. Crawford, 773-41A

L. O'. Dworjanyn, 779-2A

H. H. Elder, 704-S

S. D. Fink, 773-A

F. F. Fondeur, 773-62A

J. R. Fowler, 704-3N

D. T. Hobbx, 773-A

M. Howell, 704-196N

E. W. Holtzscheiter, 773-A

R. A. Jacobs, 704-3N

R. T. Jones, 704-3N

P. S. Kirkland, 703-46A

E. J. Kosiancic, 704-3N

L. F. Landon, 704-T

D. P. Lambert, 704-1T

T. J. Lex, 703-H

C. P. McGinnis, ORNL

E. T. Murphy, 992-3W
D. J. McCabe, 773-42A

J. W. McCullough, 703H

C. A. Nash, 773-42A

L. M. Nelson, 773-43A

L. M. Papouchado, 773-A

R. A. Peterson, 773-A

S. F. Piccolo, 704-3N

M. R. Poirier, 676-T

J. Reynolds, 704-196N

K. J. Rueter, 706-S

P. L. Rutland, 704-196N

P. C. Suggs, $704-3 \mathrm{~N}$

W. L. Tamosaitis, 773-A

G. A. Taylor, 704-196N

W B. VanPelt, 773-43A

D. D. Walker, 773-A

W. R. Wilmarth, 773-42A

TIM, 703-43A

WPTS Files, 773-A, c/o C.C.Canada, 773-A ITP files, c/o Cathy Smalls, 241-147H 